\title{
The Culture of Memory: The Approach of Reyes Mate
}

\author{
Katarzyna Gan-Krzywoszyńska (Adam Mickiewicz University, Poznań) \\ Piotr Leśniewski (Adam Mickiewicz University, Poznań)
}

To Alicja Nyczak

In general, the theme of memory in Western culture is quite pervasive, but we can still find cases, even in contemporary situations, when the narration of extremely violent events, especially when told from the victim's point of view, is considered controversial. What is more, the situation gets worse when it is based on a true story, and paradoxically, accusations are made, usually due to the fact that the presentation is "too realistic." This kind of allegation, concerning even works of art, is very interesting in the context of the culture of memory. We seem to care about commemorating victims and injustices, we seem interested in the victim's version of history, but at the same time, we consider, for instance, scenes of rape "too realistic" ("Irreversible" Gaspar Noé) and extreme sexual violence inappropriate ("A Serbian Film"). The director of this very controversial movie, Srdjan Spasojević, said in an interview concerning the problems with censorship of his work:

It doesn't even matter to the censors that the film fights against the bad things that we're talking about. Of course, it shows a lack of freedom of speech, but it also covers up crime. The film is a statement from the victim, but they're not allowing us to talk about what happens. It's not my fault, it's not the victim's fault that these things are bad. It's my testimony and they're forbidding me from telling it, because it's too hard to watch. Well, I'm sorry, they should prevent the crime, not censor me. ... You cannot fight against that kind of violence if you don't say anything about it. ... Concerning "A Serbian Film", it's not about looking for a metaphor to present our way of life or my feelings. It came naturally, because after all these wars in Serbia, we have started to experience our lives as pure exploitation. In the kind of job you have to take to feed your family, you'll end up being viciously exploited by your employer or the rulers. So pornography is used as an image for everyday life, it's normal. If he did anything else, Milos would still end up with the same kind of problems. Anything in our lives and our culture is pornographic ${ }^{1}$.

${ }^{1}$ http://www.electricsheepmagazine.co.uk/features/2010/12/05/a-serbian-filminterview-with-srdjan-spasojevic/, see also: BRÛLE! SERBIAN FILM, BRÛLE! Une entrevue avec Srdjan Spasojevic de A SERBIAN FILM - 
Moreover, Gaspar Noé said on many occasions that his goal was to show rape/violence from the victim's perspective, so why is it still-or at allcontroversial?2 Perhaps herein lies the very origin of indifference and, at the same time, the covering up of a crime. Is indifference and lassitude a crime, as Marek Edelman and Edmund Husserl have claimed?3. Do we (unintentionally) take side of the malefactor censoring the victims' testimonies? Moreover, perhaps the wrongdoer profits from the fact that others would rather not hear or know about injustices, especially violent ones. We are deeply drawn to beautiful stories, while painful stories, if they are not sensational, attract little or no attention.

This is why, for example, as Anne Applebaum has noted, communist crimes have never been decidedly condemned. Because they were, in many instances, simply too boring 4 .

\section{Memory of Injustice Against Hermeneutic Death: Barbarism As an Integral Element of Our Civilization.}

Barbarism, extreme violence, is present in the universal history of mankind. The Holocaust is not the work of crazy man, but the end of a process that involves the best of occidental culture. Reyes Mate agrees with Adorno in his claim that every cultural artifact is at the same time barbarian. Obviously, this does not mean that culture and barbarism are the same; however, they both need to be considered in the process of understanding reality, for they are equally significant (Mate 2003, 23-24). This hidden, dark and forgotten side of reality, its historia passionis, is an integral part of the present. Oblivion in this case means a new (silent) injustice.

Western culture has improved, according to Reyes Mate, the ability to "inflict" hermeneutic death, consisting of erasing the traces of a crime by

http://www.fantasiafestival.com/blog/fr/festival-fantasival/brule-serbian-film-

brule-une-entrevue-avec-srdjan-spasojevic-de-a-serbian-film\#sthash.q9MreHB7.dpuf

2 We would like to quote Noé's answer to the critics of the violence in Irreversible:

"Violence is in life; it's part of human experience. I had problems with the French critics, because they don't like seeing France portrayed in this way. Interestingly though, most of the people who are offended have not been women, but men." See: http://www.egs.edu/faculty/gaspar-noe/biography/

${ }^{3}$ Edelman's question "Indifference and a crime are the same thing?" (Indiferencia $y$ crimen ison lo mismo?) is the motto of Reyes Mate's book Memoria de Auschwitz (Mate $2003,9)$.

${ }^{4}$ We would like to quote another fundamental opinion of Anne Applebaum from this book: "The more we are able to understand how different societies have transformed their neighbors and fellow citizens from people to objects, the more we know of the specific circumstances which led to each episode of mass torture and mass murder, the better we will understand the darker side of our own human nature [emphasize ours - K. G.-K. \& P. L.]. ... Totalitarian philosophies have had, and will continue to have, a profound appeal to many millions of people. ... We need to know why and each story, each memoir, each document in the history of the Gulag is a piece of the puzzle, a part of the explanation. Without them, we will wake up one day and realize that we do not know who we are" (Applebaum 2004, 514). 
depriving the crime of its significance. This ability to blur these traces can be described as the "invisibilization" (invisibilización) of the crime. If it is true that the victim (defeated one) is not safe as long as the villain (winner) is on the loose, as this can-besides threatening the physical death of the body condemn the victim to hermeneutic death. Likewise, the villain (winner) remains restless when there is still a trace-even the smallest-of what actually took place. Memory thus enables the narrative of specific cases of injustice, of wrongs done to the innocent. Memory is also a prerequisite for justice. The question then arises: how should we think about doing justice, about satisfaction, and about a pertinent theory of justice that would take into account those cases of injustice that have already been definitively forgotten? According to Reyes Mate, Tal es la pregunta de la Filosofía [Here's a philosophical question] (Mate 2011, 292; Leśniewski 2014, 35, 96-97). This question is disturbing because man by nature cannot resign from redress; however, he lacks an absolute memory that embraces all suffering, all cases of injustice that exceed the capacity of the human mind.

It is therefore necessary to formulate an adequate theory of injustice and within its framework consider wrongs that have been definitively forgotten. We should also take into account all those cases of injustice that have been remembered and, at the same time, ponder over the issue of compensation. First of all, we have to carefully narrate injustices (hacer una cuidadosa narrativa). Reyes Mate distinguishes harms that can be satisfied (reparables) and compensated for at least that part of the society that has preserved its memory. Laws passed in relation to historical memory which aim to make amends-materially or immaterial - to communities of victims (colectivos victimizados) constitute a visible step in the right direction. However, there are cases of injustice beyond repair (irreparables), and here Reyes Mate proposes commemorating harm that can no longer be satisfied. Such an act of commemoration would constitute at the same time recognition of the debt owed to the victims of the past, and would also be an expression of mourning after them. He admits at the same time that such an act of commemoration is a very humble form of justice. However, it is of fundamental importance (Mate 2011, 31-70; Leśniewski 2014, 33-39).

\section{Memory of Guilt and Responsibility.}

Even if such a form of redress would be rejected, it would mean that justice is not determined by the suffering inflicted upon the victims, but by the measure of the executioner-or in accordance with his capacities for redress (compensation), or it is determined by the penalty he could receive. The memory of cases of injustice is therefore extremely important because even if it does not involve material compensation, it recognizes the right of victims to demand justice. There are different approaches to exploring these areas which attempt to embrace memory, including historical, legal, political and philosophical approaches. Following Reyes Mate, we propose an anamnestic perspective. According to the historical approach, attention is focused on 
narrating events, at least in the most likely way. But the "explanatory enthusiasm" in this sense of history in no way pretends - or at least should not pretend-to morally evaluate events from a historical narrative. In the anamnestic perspective, harm and suffering are not cases of inequality, but always the results of personal projects or community (projects) composed of people who can be held liable. Of course, history also talks about the defeated, but only as the spoils of war - not from the perspective of the defeated, the victims. Legal sciences specialize in the identification and classification of crimes. In accordance with the anamnestic perspective, strong emphasis should be placed on guilt. Laws are applied to determine the weight of a crime and the corresponding penalty. While guilt is a moral concept, the content of which embraces the relation between the consciousness of an acting subject and the victim's harm. In this sense, guilt takes longer than punishment-it does not lose its validity even after the punishment designated by law expires.

\section{Memory as a Way to Reconciliation.}

Memory is therefore not justice; it is rather the beginning of a process that culminates in reconciliation. Reconciliation in the religious sense is a liturgical rite that restores sacred the character to profanated places. If we extend this semantic field of the term, and if we assume that it refers to the restoration of the sacred character of any space-including the public sphere-then we repeat with Lévinas that it is impossible to build a genuinely free society without the idea of metaphysical mystery. On the margins, let us note that Mircea Eliade in his Treaty on the History of Religion uses two termsconsecration of space and construction of sacred space. Reconstruction of the anamnestic perspective does not regulate anything, just the opposite: it effectively implements a procedure that complicates everything becausemetaphorically speaking-it "opens old wounds." And, of course, thus understood, memory can also be used as a tool for revenge.

Reconciliation in Reyes Mate's approach would be a form of integral justice, with modest possibilities for the present. In the anamnestic perspective, past injustices are re-embodied. A fundamental issue always present is narration-telling about various injustices and sufferings. How to do justice to the people who have been hurt? The key word in this case is redress (reparación). What cannot be compensated for should be commemorated. In relation to public harms, there are two key terms: (1) citizenship, i.e. the effective recognition that the victim is (again) a full-fledged citizen, and (2) reconciliation. (Mate 2011, 297; Leśniewski 2014).

Western culture is slowly discovering that a political crime always involves a deep fracture in social structures and leads to the (at least cultural) impoverishment of the society in which it was committed. The process of reconciliation-as proposed by Reyes Mate-would consist of the recovery by the society, within the society and for the society of both the victims and the villains (victimarios). The victim is restored by political recognition. The situation is different in case of the perpetrators (criminals). Reconciliation is 
impossible without forgiveness, which for the victim is free (gratuito), but the villain incurs certain costs. The first consequence, the first cost, which the executioner must bear is the recognition of his guilt in the presence of the victim (and society), and the recognition that the harm suffered by the victim was an injustice. The second consequence, the cost of obtaining forgiveness, is the willingness to face his past violence in order to construct a politics of nonviolence now, that is, (A) confession (and subjection to penalty) and (B) the desire to pay for the harm and to repair the injustice or to be involved in its commemoration. Both repair and compensation for harm are due to the victim, but also to society. These consequences constitute the moral transformation of the executioner. That transformation is the second condition for the forgiveness that the executioner obtains from the victim (Mate 2011a, 44-46).

Of course, one should remember that justice is not only about punishing the perpetrators, because it is more important to reflect on the victims - on their redress or their commemoration. It can thus be seen that memory reminds society about injustices and demands in each case an adequate response, which sometimes takes the form of compensation, and other times commemoration of what is already beyond repair. This is precisely the process upon which reconciliation is founded. It seems that contemporary nations steeped in previous-often bloody-conflicts discover with time that it is not oblivion, but memory which helps to maintain peaceful coexistence.

\section{Memory As an Answer To the Failure of Knowledge.}

In Auschwitz, extreme forms of inhumanity and suffering elude and transcend cognition. This is why, according to Reyes Mate, memory gives us access to reality that is hidden from conceptual knowledge. Like Michel Foucault, Reyes Mate claims that knowledge, especially since the Enlightenment, has been concerned with the present, and thus, scientific knowledge studies only things in the here and now, while no science study things that do not exist. Memory lets us see that reality also consists of things that do not exist (Mate 2003, 23).

There is an essential difference between discovering and revealing. These two means of cognition have been described by Benjamin as "knowledge" (what we enlighten with the light of our eye) and "truth" (what is shown or introduced to us). This distinction opens the way for memory, for there are events or aspects of events that escape our knowledge, that are, like Auschwitz, unthought and unthinkable. Therefore, memory is a consequence of two experiences: that unthought exists, i.e., that knowledge/cognition is limited and that unthought has taken place and is thus transformed into what gives food for thought (Mate 2011a, 33-37).

Memory is analyzed as a concept within history, philosophy, theology, politics and literature (as a sentiment, knowledge, private and public memory, in opposition to the future, and as its ally); however, in line with Benjamin, the new approach involves not only considering memory as knowledge but as the foundation for all knowledge, not a category a posteriori, but a priori (Mate 
2011a, 39). This is where the obligation of memory comes from. When we are aware of the limits of knowledge/cognition and of its ability to "invisibilize" suffering. Memory means taking responsibility for the unthinkable by means of knowledge/cognition; its having taken place provides us with food for thought. Just as Auschwitz was unthinkable and yet took place, it interpellates, questions, "gives rise to thinking" (lo que da a pensar), and becomes the starting point of reflection (Mate 2003, 131-137). Reyes Mate has noted that memory constitutes a demanding philosophical program which obligates us to rethink everything in light of barbarianism (Mate, 2013).

Most of all, this concerns rethinking the truth, which means not reducing reality to factuality, recognizing that non-facts, the nameless, non-subjects are also a part of reality. According to Reyes Mate, philosophy found reasons not to consider them to be important, significant objects of reflection. Benjamin and Levi saw in this a process of "invisibilization," a strategy that is useful for the victor who seeks not only the physical, but also the hermeneutic death of the victim. Now the "invisibilization" of injustice is occurring not only by means of negation or denial, but-and Reyes Mate claims that Europe is a champion in this second strategy-by means of "invisibilizing" victims and depriving injustices of meaning.

Secondly, in this philosophical program, we also need to rethink politics from the perspective of Auschwitz, which is considered here the cradle of the new European politics. Let us recall that Henryk Elzenberg claimed that Auschwitz was avant-garde, not an aberration, the beginning of a new world, something that changed everything. The very same idea was expressed by Jorge Semprún, who during his last participation in the commemoration of the liberation of Buchenwald invited Europeans to go there to meditate on Europe's origins and values. He was aware that this was his last visit and that he would not be alive for the next ceremony; therefore, his words should be considered testimony of a great man and camp survivor. He thus invites everyone to Buchenwald to search for the roots of Europe in a place where tens of thousands were victims of a Nazi and Stalinist camp“5.

The last main part of Reyes Mate's philosophical program concerns ethics. Ethics must also be rethought from the perspective of the experience of Auschwitz. The foundations of contemporary ethics are based on the humanitarian prejudice that all human beings are born with the same dignity. The revolution in ethics came from a change in direction, since morality, dignity and even humanity are not a starting point, but an aim of conquest. We should not ask about the dignity of the deported, but about our own, the dignity of those born after Auschwitz. The ethical attitude within this program consists in taking responsibility for the inhumanity of the other. Therefore, it

5 Husserl was quoted recently also by Bauman: "Eighty years ago Edmund Husserl warned-so Nicolas Truong reminds us-that 'the gravest danger menacing Europe is its lassitude'. Time marches on, but warnings do not age. Time to dismiss them as outdated has not yet arrived. Neither is it likely to arrive in the foreseeable future" (Bauman 2014). 
is the end of an ethics of good conscience, and the beginning of the era of an ethics of alterity and compassion.

According to Theodor Adorno, Reyes Mate claims that we must not only remember and commemorate Auschwitz and all the historical atrocities as elements of the past, but most of all, we should consider them as integral elements of our present. Our reality is constructed on cadavers, on ruins, on the ashes of past victims. It was here, even if we later built supermarkets or parks, or abandoned the area. "It was here" calls for reflection on moral and political topicality, and on the presence of human barbarism in the construction of humanity. When we see, for instance, the pyramids or the Great Wall of China, we see only the monument; however, we should also see the suffering it caused as the result of the forced labour used in its construction. As we have already mentioned, the anamnestic perspective also questions the Holocaust as being the work of insane men. It is a consequence of our civilization, and, as shown by Reyes Mate, is connected with idealistic (as we would today call every variant of anti-realism) and Enlightenment philosophy. Memory is advocating for the hidden dimension of our reality.

The author of El tratado de la injusticia goes back to Jewish thinkers who did not personally experience the concentration camps, but who saw them coming. They include Franz Rosenzweig, Franz Kafka and Walter Benjamin. Reyes Mate calls them avisadores del fuego; they warned of disaster, and were in a way prophets and visionaries, but they were essentially fine analysts and intense observers of the present. At the same time, if we consider the problem of memory, it is because oblivion has dominated our modern culture ${ }^{6}$. We are continuing the same trends in philosophy, reading the same authors the same way, listening to the same masters, as if nothing happened 7 . Therefore, Reyes Mate, Rosenzweig, Kafka and Benjamin, who anticipated the catastrophe, should become our guides, for perhaps we are finding ourselves in the same situation just before a disaster. Thus, we will briefly present the signs of a coming catastrophe (Mate \& Mayorga 2000, 45-65).

Rosenzweig forewarned about the danger in the totalitarian tendencies of idealism (not only German idealism, but in general philosophy from Ionia to Jena) that potentially converted it into an "ontology of war." This derived from the fact that in idealistic philosophy, which unifies being with thought, reality is reduced to what can be thought, and only real means can be object of knowledge/cognition. Moreover, the insignificance of an individual death opens the way for the justification of a crime, most of all a political one. Paradoxically, when Rosenzweig reclaims the dignity of an individual death,

6 The very same idea we can find in Bauman's works, when he asks why our contemporaries who did not experience the atrocities of WW II or the Soviet forced labor camps should be interested in studying, understanding and explaining totalitarianism (Bauman 2007, 24).

${ }^{7}$ In his new book La piedra desechada Reyes Mate claims that still, in spite of regular commemorations and initiatives to save the testimonies and memories of victims, in terms of philosophical or cultural revolutions we observe the lack of fundamental change. 
his goal is the affirmation of life. The importance both of individual death and of life prevent him from justifying crimes (and genocides) by any idea of the whole (be it race, nation, religion, progress etc.). He also saw the danger of a new nationalism, which is something more than merely a political proposal, since its messianic character leads to exclusion and fundamentalism (Mate \& Mayorga 2000, 46-52).

According to Reyes Mate, the essential alert from Benjamin concerns a radical ambiguity within the concept of progress itself. While Bauman talks about the hidden possibilities of modern society, for Benjamin barbarism in general and fascism in particular are not the opposite of progress, but examples of its possibilities. What is more important and what needs to be rethought is the fact that for the victim the possibility is always the rule. We must change our perspective and stop looking from the winner's point of view. If progress is based on victims as a necessary cost and is still considered a success, nothing will ever change. Memory here enters into the solution, since, as Benjamin has noted, there is an alternative between the future and progress.

Benjamin already saw in Kafka a prophet, especially in his indication of the fascist reduction of man to bare life in the recurrent animalization of his characters, as well as the denial of the other in those presented as victims of non-communication. Using silence and paradoxes, the author of The Trial reveals the secret codes of modern barbarity, i.e., the perverse character of technology, the destruction of the subject by modern bureaucracy, and the violent nature of politics. In his writings, Kafka assumed the place and point of view of the victim, giving surprising beauty to failure. He reduces his characters to almost nothing, to insignificant human beings, but, out of this "bottom of the barrel," he paradoxically finds not only beauty, but also hope. While Rosenzweig starts from the fear of death to discover beauty and affirmation, Kafka uses the gradual disappearance and desperation of his characters to make them reach hope (Mate \& Mayorga 2000, 59-65).

All of these examples lead Reyes Mate to the notion of a "culture of longing," when we experience a burning lack of something, we start to miss it and look for it determinedly. This is when a crisis can became an opportunity, since a void is something more than nothing. Therefore, Auschwitz, Buchenwald, the Gulag, or any extreme violent experience should be a starting point for reflection within a culture of memory. Let it show what we miss and yearn for.

\section{The Memory of Injustice as a Fundamental Philosophical Category.}

As we mentioned above, memory constitutes a demanding philosophical program and has become at the same time an epistemic imperative and fundamental philosophical category. Truth, politics and ethics should be reconsidered within this new project from the barbaric, extreme violence experienced in Auschwitz. One of the foundations of this program is the 
authority of suffering, which leads towards the individual (with "the other" representing the universal). The New Thinking of Franz Rosenzweig and Reyes Mate's conception of memory are based on a paradox between the necessity of knowing and the impossibility of understanding. Unthought and unthinkable happened. It is a revolution in philosophy, a methodological revolution that is radical if we agree that the best of our civilization, our values, is forever contaminated and that man as we know him has died8.

The new method in philosophy, in other words the anamnetic perspective, consists in taking the point of view of the victim and giving the priority to the authority of suffering. In 1996, Reyes Mate wrote: The crisis is not new, it is as old as the century. A program of memory is opposite to oblivion, which transforms crisis into tragedy. It is also about the responsibility of the reader, who is obliged to continue the testimony. So perhaps the fact that we refuse to see certain dramatic, painful, disturbing stories is a means of pretending that they never really happened. Reyes Mate's recent book is entitled La piedra desechada, which means "the rejected stone." The victims were these rejected stones, but there is a new proposal to make them the cornerstones of our new culture of memory9.

\section{References}

A Serbian Film: Interview with Srdjan Spasojevic, 5 December 2010. Retrieved from:

http://www.electricsheepmagazine.co.uk/features/2010/12/05/aserbian-film-interview-with-srdjan-spasojevic/.

Applebaum, A. 2004. Gulag. A History of the Soviet Camps. London: Penguin Books.

Bauman, Z. 2007. „Rozważania u kresu drogi.” Tygodnik Powszechny 49/2007: 12-09.

Bauman, Z. 2014. "Quo vadis, Europe?". Open Democracy, 2 June 2014. Retrieved from: http://www.opendemocracy.net/can-europe-makeit/zygmunt-bauman/quo-vadis-europe.

\footnotetext{
${ }^{8}$ Let us remind that the The Star of Redemption by Franz Rosenzweig begins precisely with the phrase "All the knowledge of the universe begins with death, in the fear of death. But it ends with showing the new direction: Whither then, do the wings of the gate open? Thou knowest it not? INTO LIFE" (Rosenzweig 1971, 3 and 424).

${ }^{9}$ Similarly, within the dialogical paradigm in philosophy a new language is postulated. Furthermore, the old language could even persecuted victims, as Elie Wiesel said, "Language failed us" (Wiesel, 1986). The same idea of the failure of culture is at the center of Jonathan Littell's writing, he directly said in one interview "Culture did not save us from anything. The Nazis are proof." (Littell, El Pais, 27. October 2007).
} 
Leśniewski, P. 2014. Społeczeństwo dialogu. Prolegomena do teorii rekoncyliacji. Poznań: Kontekst.

Littell, J. 2007. "La cultura no nos protege de nada. Los nazi son la prueba (interview)." El País, 27 October 2007.

Mate, R. 2002. "O sofrimento do inocente e a universalidade da redenção." Cultura 15: 289-305.

Mate, R. 2003. Memoria de Auschwitz. Actualidad moral y política. Madrid: Editorial Trotta.

Mate, R. 2011. Tratado de la injusticia, Barcelona: Anthropos.

Mate, R. 2011a. Por una justicia anamnétic. Iglesia Viva 247: 29-48.

Mate R. 2013. La piedra desechada, Madrid: Editorial Trotta.

Mate R. \& Mayorga J. 2000. Los avisadores del fuego: Franz Rosenzweig, Walter Benjamin y Franz Kafka. Isegoria 23: 45-67.

Rosenzweig, F. 1971. The Star of Redemption. Trans. from the $2^{\text {nd }}$ edition of 1930 by W. H. Hallo. New York-Chicago-San Francisco: Holt, Rineheart \& Winston.

Wiesel, E. 1986. "Hope, Despair and Memory. Nobel Lecture." Retrieved from: http://www.nobelprize.org/nobel_prizes/peace/laureates/1986/wies el-lecture.html. 


\title{
Katarzyna Gan-Krzywoszyńska (Poznań) Piotr Leśniewski (Poznań)
}

\section{The Culture of Memory: The Approach of Reyes Mate}

\begin{abstract}
The aim of the article is to present Reyes Mate's project for a culture of memory. Western culture/tradition tends to erase and blur the traces of crimes (even genocides) in order to achieve/restore peace; however, at the same time, this leads to ignoring the victim's suffering and, in consequence, helps the wrongdoer. Following Reyes Mate, we argue that a memory of past injustices must constitute an integral part of the present and is the only means to prevent the hermeneutic death of victims. Any project for justice must put victims at the center of reflection. Memory is the beginning of the process that leads to reconciliation, for it makes it possible to redress both the victim and society. Moreover, it enables us to reclaim both the victim and wrongdoer as members of society. A culture of memory would also be a response to the failure of knowledge. Cases of extreme violence elude and transcend cognition; they are not only unthought but also unthinkable. Therefore, memory is a consequence not of discovering but of revealing the past: it follows from the fact that unthought exists and the unthinkable happened, which proves that our knowledge is limited and that we are able [and eager] to "invisibilize" victims' suffering and depriving injustices of meaning. This is why memory should be the starting point for reflection on a new philosophical program against lassitude and oblivion, as well as on idealistic/anti-realistic and Enlightenment ideas. Memory reveals hidden aspects/dimensions of our reality and becomes at the same time an epistemic imperative and fundamental philosophical category.
\end{abstract}

Key words: Memory, victim, injustice, violence, reconciliation

Doi: $10.14746 /$ eip.2014.2.16 